January 2015

\title{
Globalizing Up Corporate Law
}

Franklin A. Gevurtz

University of the Pacific, McGeorge School of Law

\section{Recommended Citation}

Franklin A. Gevurtz, Globalizing Up Corporate Law, 68 SMU L. REV. 741 (2015)

https://scholar.smu.edu/smulr/vol68/iss3/15

This Tribute is brought to you for free and open access by the Law Journals at SMU Scholar. It has been accepted for inclusion in SMU Law Review by an authorized administrator of SMU Scholar. For more information, please visit http://digitalrepository.smu.edu. 


\title{
Globalizing Up Corporate LaW
}

\author{
Franklin A. Gevurtz*
}

$I$

am pleased to participate in this symposium dedicated to the late Professor Alan Bromberg. One feature of Professor Bromberg's impressive body of scholarship is its breadth-addressing topics ranging from partnership law to securities fraud litigation-making us glad that Professor Bromberg never followed the advice sometimes offered to new law professors that one should pick a niche for one's scholarship and stick to it. In this spirit, this essay looks at several recent cases on topics ranging from controlling shareholder transactions, to the monitoring duties of corporate directors, and finally to insider trading. The common theme of these cases is that they involve examples of what I refer to as "globalizing up."

A frequent criticism of globalization is that it produces a "race to the bottom" as multinational corporations engage in regulatory arbitrage by moving activities to nations with less legal protections accorded to workers, the environment, and so on. ${ }^{1}$ Others have argued that globalization may actually lead to an increase in legal protection-trading or globalizing up. ${ }^{2}$ One example is the "California Effect" that occurs when multinational corporations find it more efficient to produce products meeting the standards imposed by the most demanding jurisdiction, rather than tailor products to differing standards. ${ }^{3}$ This essay contributes to the dialogue by looking at globalizing up in the corporate law context and specifically at examples in which globalization led to greater legal protections for minority shareholders against self-enriching conduct by controlling parties or large shareholders.

One aspect of globalizing up in corporate law is the importation of corporate laws and corporate governance institutions by developing nations seeking to attract foreign capital for local corporations. ${ }^{4}$ The spread among nations of requirements for independent directors may, in part, be Law.

* Distinguished Professor of Law, University of the Pacific, McGeorge School of

1. E.g., Debora L. Spar \& David B. Yoffie, A Race to the Bottom or Governance from the Top?, in Coping with Globalization 32-33 (Aseem Prakish \& Jeffrey A. Hart eds., 2000).

2. Id. at $41-43$.

3. E.g., David A. Vogel \& Robert A. Kagan, Introduction: National Regulations in a Global Economy 9, in Dynamics of Regulatory Change: How Globalization Af. fects National Regulatory Policies (David A. Vogel \& Robert A. Kagan, eds. 2004).

4. E.g., OECD, Reform Priorities in Asia: Taking Corporate Governance to A Higher Level 15 (2013). 
an example of this. ${ }^{5}$ Others have explored this development. ${ }^{6}$ This essay explores a different aspect of how globalization increases protections of minority shareholders. This occurs when, as a result of international capital flows, foreigners become subject to a different nation's more demanding corporate law.

To illustrate the phenomenon, this essay will discuss three recent cases. Part I of this essay will discuss the Southern Peru Copper litigation in the Delaware courts. ${ }^{7}$ In this litigation, the Mexican majority shareholder of a Delaware corporation discovered to its dismay that Delaware courts may impose huge liability for the sort of expropriation from a controlled corporation commonplace in Mexico.

Part II of this essay gives another example of Delaware courts defying a "defendant friendly" stereotype when dealing with foreign controlled Delaware corporations. Specifically, this part will discuss the Delaware Chancery Court's ruling in the Puda Coal litigation ${ }^{8}$ requiring particular vigilance by outside directors of Delaware corporations whose business is overseas.

Part III of this essay switches gears to a case imposing a more stringent non-U.S. law on a U.S. actor. Here, we encounter England's Financial Services Authority fining David Einhorn and his Greenlight Capital investment fund ${ }^{9}$ for dumping shares of an English company after receiving non-public information from the company in a situation in which Greenlight's sales would have been legal under U.S. law.

Finally, this essay concludes with a brief discussion of some implications of the phenomenon of globalizing up illustrated by these cases.

5. E.g., Jeffrey Lawrence \& Geof Stapledon, Do InDEPENDENT DiRectors AdD VALUE? 6 (1999), available at http://www.law.unimelb.edu.au/files/dmfile/ IndependentDirectorsReport2.pdf.

6. E.g., Shafi Mohammad, The Importance of Effective Corporate Governance 4 (Sept. 11, 2004), available at http://ssrn.com/abstract=617101. For a more cynical view of the spread of corporate laws and corporate governance institutions, see Franklin A. Gevurtz, The Globalization of Corporate Law: The End of History or a Never-ending Story?, 86 WASH. L. REV. 475 (2011).

7. In re Southern Peru Copper Corp. Deriv. Litig., 52 A.3d 761 (Del. Ch. 2011), aff'd sub nom. Americas Mining Corp. v. Theriault, 51 A.3d 1213 (Del. 2012).

8. In re Puda Coal Shareholders Litig. (Del. Ch. February 6, 2013), available at http:// us.practicallaw.com/cs/Satellite?blobcol=urldata\&blobheader=application\%2Fpdf\&blob $\mathrm{key}=\mathrm{id} \&$ blobtable $=$ mungoBlobs\&blobwhere $=1247445852518 \&$ ssbinary $=$ true.

9. Financial Services Authority, Decision Notice (Jan. 12, 2012), available at http:// www.fsa.gov.uk/static/pubs/decisions/dn-einhorn-greenlight.pdf; Financial Services Authority, Final Notice (Feb. 15, 2012), available at http://www.fsa.gov.uk/static/pubs/final/greenlight-capital.pdf. 


\section{SOUTHERN PERU COPPER: IMPOSING HIGHER STANDARDS AGAINST TUNNELING BY CONTROLLING SHAREHOLDERS}

\section{A. Legal Protections Against Misappropriation by Controlling Shareholders}

A minimum goal for corporate law is to prevent parties controlling a corporation from taking the company's assets to the prejudice of minority shareholders and creditors (sometimes referred to as "tunneling").10 Whatever other criticisms one may justifiably make of corporate law in the United States, it seems to have done an acceptable job of achieving this objective. ${ }^{11}$ While this might seem too modest an accomplishment to note, the widespread misappropriation of corporate assets by controlling shareholders in some other countries ${ }^{12}$ suggests that this achievement is more significant than one might have thought.

It has become foundational for comparative corporate law scholarship over the last couple of decades to note the difference in shareholding patterns for the largest firms in the United States and England versus most of the rest of the world. ${ }^{13}$ Shareholdings of the largest corporations in the United States and England are commonly so widely dispersed that no individual shareholder or even cohesive group of shareholders owns a large enough percentage of these corporations' outstanding stock to control the company; instead, a self-perpetuating management governs these firms. ${ }^{14}$ By contrast, a small number of persons (commonly a family) owns a large enough percentage of the outstanding stock to control even the largest corporations in most other nations. ${ }^{15}$ Each system has a weakness: wide dispersal of shareholdings creates an agency problem in which management, having only an attenuated stake in maximizing profits for shareholders, can indulge in inefficient decisions (e.g., empire building, excessive compensation). ${ }^{16}$ By contrast, the presence of controlling shareholders curbs the agency problem, but risks the controlling shareholders obtaining more than their proportionate share of the corporation's profits through favorable transactions with the company (so-called private benefits of control). ${ }^{17}$

Nations vary in the effectiveness with which their legal regimes curb the ability of controlling shareholders to extract private benefits of control. The United States comes out well on this scale-indeed, otherwise

10. Simon Johnson et al., Tunneling, 90 AMER. ECON. Rev. 22 (2000).

11. E.g., Ronald J. Gilson \& Jeffrey N. Gordon, Controlling Shareholders, 152 U. Penn. L. Rev. 785, 793 (2003).

12. E.g., Ronald J. Gilson, Controlling Shareholders and Corporate Governance: Complicating the Comparative Taxonomy, 119 HARv. L. Rev. 1641, 1648 (2006).

13. E.g., Brian R. Cheffins, Corporate Governance Convergence: Lessons from Australia, 16 Transnat'L Law. 13, 15-18 (2002).

14. Id.

15. E.g., Gilson, supra note 12 , at 1645 .

16. E.g., Franklin A. Gevurtz, Corporation Law 236-37 (2d ed. 2010).

17. E.g., Gilson, supra note 12, at 1651-52. 
shares presumably would not have dispersed to the point where most of the United States' largest corporations lack controlling shareholders. ${ }^{18}$ This is a function of both substantive and procedural rules. Substantively, the intrinsic fairness test demands the controlling shareholder prove the merits from the company's standpoint of any transaction with the corporation in which the controlling shareholder gains advantages not shared proportionately with the minority. ${ }^{19}$ Procedurally, the availability of derivative and class actions enables shareholders having even a small stake to challenge the conduct of a controlling shareholder, with the action financed by the prospect of attorney's fees paid out of the corporation's or class's recovery. ${ }^{20}$

Other nations have been less effective-explaining, at least in part, the absence of corporations without controlling shareholders in many nations. ${ }^{21}$ Again, this is a function of substance and procedure. Substantively, Professors Johnson, La Porta, Lopez de Silanes, and Shleifer describe in their noted article, Tunneling, ${ }^{22}$ how courts in some countries (they discuss cases from France and Italy) apply deferential standards when reviewing challenged transactions in which controlling shareholders extract benefits at the expense of the corporations they control. Procedurally, limitations on collective or derivative actions impose significant barriers in many countries to actions by minority shareholders, while government enforcement actions do not fill the slack. ${ }^{23}$

A number of studies have measured the extent to which controlling shareholders extract private benefits of control in countries with weak legal protections. ${ }^{24}$ Among nations doing poorly in such studies is Mexico: one study estimates that controlling shareholders there expropriate over one-third of the value of the companies they control. ${ }^{25}$

\section{B. Applying Delaware law to a Mexican Controlling SHAREHOLDER}

The Southern Peru Copper litigation in the Delaware courts is a story of how globalization of corporate operations and of capital markets can expose controlling shareholders from nations with weak legal protections against misappropriation to stronger legal protections and greater potential liability. Specifically, the Larrea family and the company they controlled, Grupo Mexico, discovered that, if they wanted to control

18. Id. at 1644 .

19. E.g., Sinclair Oil Corp. v. Levien, 280 A.2d 717 (Del. 1971).

20. E.g., Luca Enriques et al., Related Party Transactions, 178 The Anatomy of Corporate Law: A Comparative and Functional Approach (2d ed. 2009).

21. E.g., Gilson supra note 12, at 1653-57 (but noting that efficient controlling shareholder systems continue even with good laws).

22. See Johnson et al., supra note 10 .

23. E.g., Enriques et al., supra note 20, at 175-76.

24. E.g., Alexander Dyck \& Luigi Zingales, Private Benefits of Control: An International Comparison, 59 J. FiN. 537 (2004).

25. Tatiana Nenova, The Value of Corporate Voting Rights and Control: A CrossCountry Analysis, 68 J. Fin. ECON. 325, 334 tbl.3 (2003). 
Delaware corporations in order to geographically diversify operations and obtain financing through U.S. capital markets, they would have to play by different rules than what they were used to in Mexico.

Grupo Mexico is a Mexican holding company, which operates railroads and mines in Mexico through its subsidiaries. While shares in Grupo Mexico trade on the Mexican stock exchange, the wealthy Mexican Larrea family owns a controlling interest in the company. ${ }^{26}$ Buoyed by high copper prices and NAFTA late in the 1990s, Grupo Mexico's CEO, German Larrea, decided to diversify geographically and obtain access to U.S. financial markets. Grupo Mexico's vehicle for doing so was to acquire the U.S. mining company, ASARCO, in 1999 through a leveraged buy-out. 27 Among ASARCO's assets was the majority voting ownership in the Southern Peru Copper Corporation. ${ }^{28}$ Southern Peru Copper began as a joint venture by U.S. companies to mine copper in the southern mountains of Peru and is a Delaware corporation with stock listed on the New York Stock Exchange. In 2003, as ASARCO was bending under the debt incurred to finance Grupo Mexico's LBO, rising claims for environmental and asbestos liability, and falling copper prices, Grupo Mexico extracted ASARCO's controlling ownership in Southern Peru Copper by having ASARCO sell its Southern Peru Copper shares to Grupo Mexico. In a foreshadowing of events to come, the U.S. district court supervising ASARCO's subsequent bankruptcy later labeled this sale a fraudulent conveyance and a breach of fiduciary duty. ${ }^{29}$

Grupo Mexico's self-dealing involving Southern Peru Copper was not over. In 2004, it decided to have Southern Peru Copper acquire Grupo Mexico's almost wholly owned Mexican mining subsidiary, Minero Mexico, through a merger and thereby bring both the Mexican and Peruvian copper mining operations together in one subsidiary. ${ }^{30}$ Grupo Mexico decided that it was entitled to Southern Peru Copper stock with a market value of $\$ 3.1$ billion in payment for Minero Mexico-albeit, by the time the deal closed, the market value of the Southern Peru Copper stock received by Grupo Mexico had risen to $\$ 3.75$ billion. ${ }^{31}$ This transaction triggered a derivative lawsuit by minority shareholders on behalf of Southern Peru Copper and a costly lesson for Grupo Mexico on Delaware corporate law.

While the Minero Mexico merger bore the trappings of accepted practice when dealing with a controlled Delaware corporation-Southern

26. E.g., ASARCO LLC v. Americas Mining Corp., 396 B.R. 298, 299-300 (S.D. Tex. 2008).

27. Id. at 300-01.

28. Id. at 300 .

29. Id at $377-80,410-11$ (the primary problems were the use of the proceeds of this sale to pay certain creditors favored over others because of Grupo Mexico's interest in obtaining loans to buy the Southern Peru Copper shares, as well as the failure to put the shares up for competitive bids).

30. In re Southern Peru Copper, 52 A.3d at 768-69.

31. This was attributable to performance by Southern Peru Copper rather than announcement of the Minero Mexico merger. Id. at 764 . 
Peru Copper having appointed a committee of independent directors with financial advisors to evaluate the transaction ${ }^{32}$ - this proved insufficient. What German Larrea and Grupo Mexico, coming from a different legal culture, did not anticipate is the degree of sophistication and skepticism with which Delaware judges would dissect parent-subsidiary dealings.

This sophistication and skepticism shows up in the discussion by the Delaware Chancery and (on appeal) Supreme Court of the process involved in approving the Minero Mexico merger. While both courts spent some time addressing whether approval by the minority shareholders of Southern Peru Copper or the committee of independent Southern Peru Copper directors shifted the burden of proof on fairness from the defendants to the plaintiffs, in the end both courts recognized the unimportance of this question to the case at hand. ${ }^{33}$ The Chancery Court made short work of the shareholder approval-noting that the failure of Grupo Mexico to make the transaction contingent on approval by a majority of the minority shareholders in effect told the minority shareholders that their votes did not matter and, in any event, Grupo Mexico had distorted and omitted material facts presented to the minority shareholders before the vote. $^{34}$

More interesting was the analysis of the motivations and actions of the committee of independent directors. One member of the committee faced conflicting pressures because of his employment by one of the founding shareholders in Southern Peru Copper. This shareholder wanted to sell out its considerable block of unregistered Southern Peru Copper stock and required Grupo Mexico's cooperation in obtaining the necessary filings under U.S. securities law in order to do so. The Chancery Court refused to go so far as to treat the simultaneous negotiation of registration rights and the Minero Mexico merger as a breach of the duty of loyalty sufficient to establish personal liability for this director. Nevertheless, it undermined the court's confidence in the committee. ${ }^{35}$ More broadly, the court viewed the committee members, despite their independence and good faith, of having fallen into a mindset too easily resulting from dealing with a controlling shareholder. Instead of an aggressive negotiation with Grupo Mexico backed by an exploration of all options and a willingness to just say no, the committee, in effect, negotiated against itself and looked for ways to rationalize the deal proposed by Grupo Mexico. ${ }^{36}$

Overlapping with this sophistication and skepticism about process is each court's careful dissection of the substance of the deal. The fundamental problem was that Grupo Mexico demanded Southern Peru Copper stock with a market valuation over $\$ 3$ billion in exchange for Grupo

\footnotetext{
32. Id. at 769-70.

33. Id. at 793; Theriault, 51 A.3d at 1242.

34. In re Southern Peru Copper, 52 A.3d at 793-97.

35. Id. at $786-87$.

36. Id. at $797-98$.
} 
Mexico's privately held subsidiary, whose value the investment bankers found to be only around $\$ 2$ billion. Rather than telling Grupo Mexico (in the colorful language of the Chancery Court) "to go mine himself," 37 the independent directors committee tried to justify the deal. They did so, not by finding some hidden value in Minero Mexico missed by their financial advisor, but rather by assuming that the market was overvaluing Southern Peru Copper's stock. The Chancery Court not only found such selfdoubt unconventional, to say the least, but also, displaying a significant degree of sophistication about mergers and acquisitions for a judge, discussed alternatives by which truly independent directors could have exploited the opportunity presented by a high market valuation of their company. ${ }^{38}$ Beyond this, both Delaware courts were underwhelmed by the defendants' argument that the committee's valuation approach made an "apples to apples" comparison, noting that the committee was only able to bridge the gap between even the internal valuations of the Southern Peru Copper stock and Minero Mexico by making the most optimistic assumptions about Minero Mexico (despite Minero Mexico being mired in financial struggles), which the committee did not make for Southern Peru Copper (despite Southern Peru Copper being a debt free company whose performance was exceeding expectations)..$^{39}$

After finding the deal unfair, the Chancery Court assessed damages of over $\$ 1.3$ billion, which, when combined with interest on the damages since the transaction, yielded a judgment in favor of Southern Peru Copper of over $\$ 2$ billion. In a particularly noteworthy part of the decision, the plaintiffs' attorneys received a staggering $\$ 300$ million in fees out of this award; $;^{40}$ all the better to encourage vigilance by prospective plaintiffs' attorneys of such transactions in the future. The combination of this sort of incentive to file lawsuits and the careful scrutiny of parent-subsidiary dealings by a sophisticated judiciary exposes controlling shareholders from nations with weak legal protections against expropriation, such as Mexico, to a very different universe when they gain control of Delaware corporations. ${ }^{41}$

37. Id. at 763 .

38. Id. at $773-74$.

39. Id. at 802; Theriault, 51 A.3d at $1247-48$.

40. Theriault, 51 A.3d. at 1252.

41. Subsequent to the events in Southern Peru Copper, Mexican corporate law changed. In 2006, a new securities law took effect, which attempts to clarify directors' liabilities for conflict of interest transactions (including favoring some shareholders over others) and to liberalize rules governing shareholder actions. E.g., Daniel Del Rio \& Juan Jose Lopez-de-Silanes, Mexico, in Directors' Liability: A Worldwide Review 93, 100-02 (2010). Formidable barriers, such as limiting shareholder actions in Mexico to plaintiffs owning a sizable percentage of the outstanding stock, remain, however. Such barriers, combined with the absence of much jurisprudence regarding parent-subsidiary dealing and the lack of a judiciary sophisticated in corporate transactions, still leave a sizable gap between minority shareholder protection in Mexico and Delaware. 


\section{PUDA COAL: ENFORCING OBLIGATIONS OF DIRECTORS TO MONITOR FOREIGN CONTROLLING PARTIES}

\section{A. Protecting Investors by Obligating Directors to Monitor}

The contemporary corporate governance model views the primary role of the board of directors as monitoring the integrity and competence of those who actually manage the company. ${ }^{42} \mathrm{~A}$ fundamental problem with this model is that the individuals managing the company-controlling shareholders or senior executives-typically select the directors. ${ }^{43}$ The result is that the rigor with which directors perform their monitoring can end up inversely proportional to the need to monitor those running the company.

Corporate law responds to the failure of directors to monitor by imposing liability for breaching the duty of care. ${ }^{44}$ The fact-specific nature of determining whether directors breached their duty through inattention makes it difficult to compare the substantive standards applied in different nations..$^{45}$ Regardless of the substantive standards, however, procedural barriers to enforcement actions in many countries, as for example China, reduce the potential liability inattentive directors face compared to the risk that directors face in the United States. ${ }^{46}$ Assuming that directors adjust their diligence to the level of liability risk they face, this means less scrutiny of controlling parties by directors in nations with poor enforcement prospects and greater scrutiny in nations with more enforcement. ${ }^{47}$

\section{B. Requiring Directors of a Delaware Corporation to Monitor Conduct of Controlling Parties in China}

Puda Coal is a poster child for the perils of Chinese "reverse mergers." In reverse mergers, parties merge private companies into moribund corporations, which had previously sold stock to the public in the United States. In this manner, parties can put their businesses into, and gain control of, corporations with publicly tradable shares without the regulatory

42. E.g., Melvin A. Eisenberg, Ralph K. Winter \& Fred S. McChesney, The Structure of the Corporation, 89 Colum. L. Rev. 1461 (1989).

43. E.g., Thomas L. Hazen \& F. Hodge O'Neal, Corporations $\S 9.2$ (1997).

44. E.g., Francis v. United Jersey Bank, 432 A.2d 814 (N.J. 1981).

45. See, e.g., Franklin A. Gevurtz, Global Issues in Corporate Law 74-79 (2006) (discussing cases from England and Japan). Exculpation provisions common in the certificates of incorporation for Delaware corporations limit the liability of directors unless they breached their duties of good faith or loyalty, thereby requiring a more egregious failure to pay attention before imposing liability. E.g., Stone v. Ritter, 911 A.2d 362 (Del. 2006).

46. Jui-Chien Cheng, Challenges Surrounding Directors' Duty of Care in Chinese Corporate Law 10-14 (working paper Jan. 2014), available at http://www.indiana.edu/ rccpb/ pdf/Jui-Chien_Cheng_oct_2013_34.pdf (describing the small fine imposed by Chinese regulatory authorities upon a director for failing to be diligent and the barriers to shareholder derivative suits in China).

47. Alternately, directors might respond to greater risk with greater selectivity in deciding which boards to join, which at least should better match the stature of the outside directors with quality of the corporation's controlling parties. 
expenses imposed upon initial public offerings. While pioneered by domestic promoters, overseas companies (particularly from China) increasingly employed this technique to gain access to U.S. capital markets. ${ }^{48}$

While not everyone, much less everyone from China, undertaking a reverse merger is a shady operator, ${ }^{49}$ the controlling parties of Puda Coal were. Puda Coal is a Delaware corporation that emerged from a 2005 reverse merger of a Chinese firm into a Delaware corporation with listed shares. ${ }^{50}$ Puda Coal's principal asset was an indirect 90 percent ownership interest in Shanxi Puda Coal Group Co. (Shanxi Coal), a Chinese firm mining and selling coal in the Shanxi Province of China. ${ }^{51}$ Ming Zhao and his brother owned over 30 percent of Puda Coal's stock. Zhao was Chairman of Puda Coal's board, while Zhao's apparent crony, Liping Zhu, was CEO.52 In 2009, Puda Coal listed its shares on the New York Stock Exchange and in 2010 it sold additional shares to the public in the United States. ${ }^{53}$ Unfortunately for anyone buying the shares, it turned out that in September 2009, Zhao and Zhu had transferred ownership of Shanxi Coal from a Puda Coal subsidiary to Zhao, who then sold or pledged the Shanxi Coal stock to an investment trust (CITIC Trust) managed by the largest state owned financial firm in China. ${ }^{54}$ A 2011 posting on the Internet exposed the fraud-the posting's author evidently having noticed references to CITIC Trust's interest in Shanxi Coal in the trust's on-line report to its investors. The price of Puda Coal's stock collapsed and the stock was delisted. ${ }^{55}$ The SEC brought an enforcement action against Zhao and Zhu. Finally, shareholders of Puda Coal brought a derivative action in the Delaware Chancery Court against Puda Coal's directors.

Zhao, not surprisingly, failed to answer the derivative suit complaint, leaving the outside directors, Lawrence Wizel and Mark Tang, hanging in the wind. Wizel and Tang's motion to dismiss the complaint against them received a frosty reception in a bench ruling from the Chancery Court. ${ }^{56}$ Wizel and Tang's attorneys did not help their cause by arguing that the court should dismiss the complaint for failure to make a demand upon Puda Coal's board to take action-even though by the time of the motion Wizel and Tang had resigned from the board, leaving Zhao as the only director to decide whether the company should sue himself for stealing. ${ }^{57}$ The more serious issue was whether the complaint stated a cause of action against Wizel and Tang for having breached their duty of good faith

48. E.g., Charles M.C. Lee et al., Shell Games: The Long Term Performance of Chinese Reverse Merger Firms, 90 The Accounting Rev. 1547 (Sept. 16, 2014), available at $\mathrm{http}: / / \mathrm{ssrn} . \mathrm{com} / \mathrm{abstract}=2155425$.

49. Id. at 33 .

50. Complaint, SEC v. Ming Zhao, 6 (Feb. 22, 2012), available at http://www.sec.gov/ litigation/complaints/2012/comp22264.pdf.

51. Id. at 6-7.

52. Id. at 5-6.

53. Id. at $6-7$.

54. Id. at $8-10$.

55. Id. at $11-12$

56. In re Puda Coal Shareholders Litig. (Del. Ch. February 6, 2013).

57. Id. at 15-17. 
in failing to notice the theft for eighteen months after it happened. The court concluded the complaint did state a claim. ${ }^{58}$

What stands out in this ruling is the court's discussion of the obligations of directors of Delaware corporations that serve as vehicles for overseas businesses. In part, the court's discussion is fairly conventional in its demands:

[I]f you're going to have a company domiciled for purposes of its relations with its investors in Delaware and the assets and operations of that company are situated in China that, in order for you to meet your obligation of good faith, you better have your physical body in China an awful lot. You better have in place a system of controls to make sure that you know that you actually own the assets. ... You better have retained accountants and lawyers who are fit to the task of maintaining a system of controls over a public company. ${ }^{59}$

Except perhaps for the demand to visit the company's operations abroad, this does not seem much different from a typical articulation of the director's duties for any public Delaware company. ${ }^{60}$ More interesting, however, was the court's warning about the extra burdens for intercultural competence on a director when the company's operations are overseas:

[I]f the assets are in Russia, if they're in Nigeria, if they're in the Middle East, if they're in China, ... there will be special challenges that deal with linguistic, cultural and others in terms of the effort that you have to put in to discharge your duty of loyalty. . . . If it's a situation where, frankly, all the flow of information is in the language that I don't understand, in a culture where there's, frankly, not legal strictures or structures or ethical mores yet that may be advanced to the level where I'm comfortable? It would be very difficult if I didn't know the language, the tools. You better be careful there. You have a duty to think. You can't just go on this [board] and act like this was an $S \& L$ regulated by the federal government in Iowa and you live in Iowa. ${ }^{61}$

Beyond this, the court stated that Wizel and Wang may have breached their duty by resigning upon learning of the fraud rather than having the company sue or take other action against Zhao. ${ }^{62}$

Puda Coal can be viewed as a compliment to Southern Peru Coppernot surprising given that the same Chancery Court chancellor (Strine) decided both. The facts in Puda Coal illustrate the impracticality of an action against controlling shareholders (as in Southern Peru Copper) when the foreign controllers loot the company and remain abroad. Puda Coal responds by imposing the burden of scrutiny on U.S. based direc-

58. Id. at 19.

59. Id. at $17-18$.

60. See, e.g., In re Caremark Int'l Inc. Deriv. Litig., 698 A.2d 959, 970 (Del. Ch. 1996).

61. In re Puda Coal, No. 6476-CS, at 21-22.

62. Id. at 23. 
tors; in effect holding them hostage and thereby indirectly imposing on foreign controlling parties more demanding U.S. corporate law.

\section{GREENLIGHT CAPITAL: BANNING ALL TRADING ON INSIDE INFORMATION}

\section{A. Insider Trading Prohibitions}

Parties controlling corporations can exploit minority shareholders by misappropriating assets from the corporation, by compelling minority shareholders to sell their shares (freeze-outs) at unfairly low prices, or by trading on inside information. ${ }^{63}$ Judicial review of transactions by controlling parties with the corporation and of freeze-outs ${ }^{64}$ addresses the first two of these avenues for exploitation. Prohibitions on insider trading address the third.

Prohibitions on insider trading trace back to the 1961 decision by the United States Securities and Exchange Commission in an administrative proceeding against the Cady, Roberts brokerage firm. ${ }^{65}$ From this beginning, prohibitions on insider trading spread around the world, slowly at first and then with increasing speed in the late 1980s and 1990s. ${ }^{66}$ Nations differ, however, in defining the circumstances under which it is illegal to trade on non-public information.

While some lower court decisions in the United States before 1980 seemed to indicate that any trading on non-public material information was illegal, ${ }^{67}$ the United States Supreme Court in a series of decisions starting that year cabined the scope of the prohibition so that the conduct is illegal only in certain circumstances. These include: trading on inside information by individuals who occupy a fiduciary relationship with the company whose stock they trade; 68 trading on non-public information obtained in a deceptive manner, most commonly through the pretense that one could be trusted not to abuse information received in confidence (misappropriation); ${ }^{69}$ and trading on information received from persons (tippers) that one knows cannot legally trade themselves and that seek some personal benefit from passing on the information for another's trading..$^{70}$

Insider trading prohibitions in some other countries, for example Ja-

63. See, e.g., William W. Bratton \& Joseph A. McCahery, Comparative Corporate Governance and the Theory of the Firm: The Case against Global Cross Reference, 38 Colum. J. Transnat'l L. 213, 293-94 (1999) (private benefits can be obtained through transactions with corporation and insider trading); Gilson \& Gordon, supra note 11, at 786 (private benefits can be obtained by transactions with the corporation, freezing out minority shareholders and the sale of control).

64. E.g., Weinberger v. UOP, Inc., 457 A.2d 701 (Del. 1983).

65. In re Cady, Roberts \& Co., 40 S.E.C. 907 (1961).

66. E.g., Franklin A. Gevurtz, The Globalization of Insider Trading Prohibitions, 15 Transnat'l Law 63, 65-66 (2002).

67. See, e.g., SEC v. Tex. Gulf Sulfur, 401 F.2d 833, 848 (2d Cir. 1968).

68. E.g., Chiarella v. United States, 445 U.S. 222 (1980).

69. E.g., United States v. O'Hagan, 521 U.S. 642 (1997).

70. E.g., Dirks v. SEC, 463 U.S. 646 (1983). 
pan, ${ }^{71}$ are narrower in their reach than the prohibition in the United States. Yet other countries, most notably the member nations of the European Union, have broader prohibitions than in the United States. Specifically, the 2003 European Union Market Abuse Directive ${ }^{72}$ commands member nations to prohibit trading by anyone who knows that he or she is trading on inside information. It also carries forth the categorical prohibitions introduced in the 1989 European Union Directive on Insider Trading. ${ }^{73}$ These prohibit trading by persons who gain inside information through management or board positions with, or by being a shareholder of, the issuer, or through their employment, profession or duties, or, in a new category added in 2003, through criminal activities.

\section{B. Enforcing English Insider Trading Rules Against a U.S. Hedge Fund}

The action by the English Financial Services Authority fining David Einhorn and the U.S. based Greenlight Capital hedge fund that Einhorn manages illustrates the potential for U.S. investors, who purchase stock in overseas companies, to run afoul of other nations' insider trading prohibitions in situations in which the trading would have been legal in the United States.

Greenlight held a large block (over 13 percent) of the outstanding stock in the English company, Punch, which operates pubs. ${ }^{74}$ In 2009 , Punch's management planned to issue a substantial amount of new shares in order to pay off certain debt of the company, but sought the reaction of its larger shareholders before doing so. Punch's investment banker contacted Punch's larger U.S. based shareholders to set up calls with Punch's $\mathrm{CEO}$, but asked the shareholders to enter non-disclosure agreements precluding the shareholders from trading Punch shares prior to public announcement of the information they would receive. ${ }^{75}$

The investment banker contacted Greenlight and requested its agreement not to trade. Einhorn refused to have Greenlight agree, but nevertheless the investment banker set up a call between Einhorn and Punch's CEO with the understanding that Greenlight had not agreed to abstain from trading. ${ }^{76}$ Punch's CEO discussed with Einhorn the possibility of a stock issuance, but declined to provide details unless Greenlight agreed not to trade for a week (by which time Punch presumably would have publicly announced the stock issue). Einhorn again refused and the con-

71. Shoken torihikiho [Securities and Exchange], Law No. 25 of 1948, arts. 190-92, 190-93. For a translation of the Japanese insider trading provisions, see generally, Tomoko Akashi, Note, Regulation of Insider Trading in Japan, 89 Colum. L. REv. 1296 (1989).

72. Directive 2003/6/EC, of the European Parliament and of the Council of 28 January 2003 on Insider Dealing and Market Manipulation (Market Abuse), 2003 O.J. (L 96) 16.

73. Council Directive $89 / 592$ of 13 Nov. 1989 Coordinating Regulations on Insider Dealing, 1989 O.J. (L 334) 30.

74. FSA Final Notice, supra note 9, at II 2.7.

75. Id. at II $3.8-3.20$.

76. Id. at of 3.21 . 
versation ended. ${ }^{77}$ Immediately after the conversation, Einhorn ordered Greenlight to sell all its shares in Punch. Greenlight had disposed of almost one-third of its holdings in Punch by the time Punch publicly announced (a few days after the call) its plan to issue more stock. The market price of Punch shares fell around 29 percent on the announcement of the stock issuance. ${ }^{78}$

It seems reasonably clear that Greenlight's sales, had they occurred here, would not have violated U.S. law. There is no evidence that Punch's CEO was tipping Einhorn in order to gain some personal benefit from passing on the information for Einhorn's or Greenlight's trading; indeed, the effort to get Greenlight's agreement not to trade shows the contrary. Einhorn's refusal to agree not to trade shows that Einhorn did not misappropriate the information from Punch through a pretense that he could be trusted with the information. Nor did Einhorn misappropriate the information from Greenlight, since Greenlight, not Einhorn, traded. Einhorn was not an officer, director or other fiduciary of Punch. Perhaps one could argue that Greenlight's large shareholdings in Punch made Greenlight a fiduciary. ${ }^{79}$ However, there is no indication that Greenlight exercised any control over Punch ${ }^{80}$ and the efforts of Punch's CEO to gain Greenlight's agreement not to trade and refusal to provide further details about the proposed issuance without such an agreement suggest that the CEO did not view the conversation as providing information to a fiduciary in confidence. ${ }^{81}$

In 2012, Einhorn found out that English law is different, when the FSA imposed a £3.6 million fine on Einhorn and Greenlight. ${ }^{82}$ Much of the FSA's discussion in the notice of the fine focused on whether the information Einhorn received in the call (given its lack of details) constituted price sensitive (material) non-public information. As far as whether there was any duty not to trade on inside information, the FSA relied on the fact that Einhorn received the information as a result of his employment managing Greenlight. ${ }^{83}$ This seems rather strange, since Einhorn did not personally trade in violation of any duty to Greenlight; rather he ordered Greenlight to trade. In other words, Einhorn violated English law because he used information received as part of his job with Greenlight in order to carry out his job by using the information on Greenlight's behalf. In any event, assuming English law tracks the broader command of the

77. Id. at Annex 2.

78. Id. at III 3.33-3.38.

79. If Punch had been a company registered under the 1934 Securities Exchange Act, Greenlight's holdings would have subjected it to Section 16(b) of that Act; meaning turning over to Punch the losses Greenlight avoided on the sales of any Punch stock Greenlight purchased within the previous six months and after becoming a 10 percent shareholder.

80. Indeed, Einhorn expressed strong opposition to Punch issuing stock during his conversation with Punch's CEO, which advice the CEO blithely ignored.

81. If Punch had been a company registered under the 1934 Securities Exchange Act, Punch's selective disclosures might have violated the SEC's Regulation FD; but this is not Einhorn or Greenlight's violation.

82. See FSA Final Notice, supra note 9.

83. Id. at $\mathbb{I l} 4.5$. 
2003 European Union Market Abuse Directive, the same result would follow without regard to Einhorn's employment. Einhorn was aware that he was in possession of non-public information, which, as stated above, makes trading illegal under national laws carrying out the 2003 directive.

\section{CONCLUSION}

In each of these three cases, globalization manifested itself in parties purchasing controlling or large blocks of stock in corporations formed under another nation's laws. The result was to expose these shareholders to corporate laws imposing greater limits on their ability to enrich themselves at the expense of minority shareholders than the limits they found in their home countries. In two cases, the limit was direct with liability for the controlling or large shareholders. In the third case, the limit was indirect through duties imposed on directors to monitor the foreign controlling shareholders.

Going forward, the interesting question is whether these cases are simply transitional, representing what will become an increasingly rare failure of parties to realize that they have bought into more demanding corporate law. Indeed, it is ironic that the more demanding corporate law in two of the cases in this essay came from Delaware-a state whose name often serves as shorthand for the race to the bottom thesis. ${ }^{84}$ Moreover, the reputation the U.S. gained as first mover in insider trading laws may have lulled Einhorn into assuming that other nations had not enacted more stringent prohibitions.

Yet, there are reasons to doubt that globalizing up corporate law will be a short-lived phenomenon as parties shy away from purchasing controlling or large interests in corporations subject to more demanding corporate laws. Underlying the Delaware court decisions seems to be a sensitivity to the Delaware brand for public corporations and a concern not to see that brand tarnished by foreign parties freeriding on it in order to take advantage of public investors in the U.S. Similarly, insider trading prohibitions are motivated by the desire to attract investors. ${ }^{85}$ Of course, parties planning to abuse controlling positions may steer clear of jurisdictions whose corporate laws crimp their style; but this then serves as a signal to prospective minority shareholders.

Moreover, there is the potential for a California effect in corporate law compliance. For example, it might be simpler for hedge funds or similar investors to adopt policies that comply with the most stringent insider trading prohibition-do not trade on non-public material information, period-rather than try to adjust trading to the insider trading laws of particular jurisdictions. Similarly, it might be easier to have all members in a multinational corporate group adhere to corporate governance prac-

84. E.g., Vogel \& Kagan, supra note 3, at 3.

85. E.g., O'Hagan, 521 U.S. at $658-59$. 
tices-independent committees, internal controls-sufficient to meet the most demanding corporate laws governing any member of the group.

Of course, critics of globalization may be less moved by increased protections for investors (minority or otherwise), as opposed to protections for workers and the environment; indeed, certain critics might view this simply as further evidence of globalization favoring the interests of those with money. Still, one must take one's victories where one can, and protecting smaller investors from expropriation by wealthier and more powerful controlling interests is worth something. 
